\title{
Status of School Library Development in Maldives
}

\author{
Easa Mohamed Sameer \\ Deputy Librarian \\ Maldives College of Higher Education. Faculty of Education \\ M. Kagi \\ Lainoofarumagu \\ Male, Republic of Maldives \\ Tele. $+(960) 736-673$ \\ Fax. +(960) 313-425 \\ E mail.ms.easa.01@mche.edu.mv
}

\section{Introduction}

The Maldives is a series of 1,190 islands atolls covering $90,000 \mathrm{sq} \mathrm{km}$, and stretching in an archipelago $823 \mathrm{~km}$ long and $130 \mathrm{~km}$ wide in the south Indian Ocean. It is a Republic, with an approximate population of 270,000. The capital city is Male, on one island of $1.77 \mathrm{sq}$. kms. Maldives maintains relations with the UN, and most of its specialized agencies, Commonwealth, OIC, the Non-Aligned Movement and SAARC.

It is not too easy to highlight the exact date as when the school libraries and their services begin in Maldives. But it is possible to say that, there was an early existence for school libraries and their services in Maldives. Most probably, the history of school libraries also can be as old as schools and their functions. Of course, it is very natural that in the early age, school libraries and their services might be too different than in the present time. These differences occurred in nature of collections, kinds of services and the ways of doing it.

Since the importance of education became understood to our leaders, the education sector and the scope became broader. As a result, private schools also came into existence in the country, whether it is in Male, the Capital Island, or in the remote areas. Some of the private schools and community schools in different shapes and names were a little bit more active than government schools in the islands.

The number of students and staff of a school vary from one to another across the 330 schools across the country. Basically it depends on the capacity and the populated area, as well as the size of the island the school is meant to serve depending on its land area, population and income.

One school holds about 1299 students with 52 staff; another school has 2614 students with 96 staff. A third school has 976 students with 45 staff. In the same manner, the size of the school libraries vary greatly from the quite large with 18,831 books to the very small collections.

Only a few schools of the largest schools have resources like CDs, video tapes, journals, newspapers, photocopiers, computer resources. Most would depend on their book and newspaper collections. 
Some libraries do offer lending services, Internet, photocopying, printing, discussion rooms, reference services and newspapers with reading facilities. Generally most provide a space for storage, and some reading opportunities with circulation.

\section{Administration and Co-ordination Systems}

The Ministry of Education is the major stakeholder for school library development. It is responsible for allocating budget, staff, and all the necessary related decisions. It is the librarians and the school administration with teachers who are involved in acquisition and introducing new services and facilities to the students and staff. The National Library has no role or involvement in any kind of process related to the development of school libraries.

In most schools there is a library trainee or assistant, and that person is supervised by the principal or an assigned teacher. They are responsible for the activities in the library.

\section{Problems and Issues in Maldives School Libraries}

There are many problems than any school library has to confront, whether the issue is related to the improvement of the services, enriching the collection, capacity of the library and staff training.

Problems related to the acquisitions of materials are matters that we may not be able to solve easily. Generally, all the orders for textbooks or any other types of materials for the library have to be places somewhere abroad. This procedure certainly has been one of the major problems for all libraries. This procedure is time consuming and slow. It causes many difficulties to provide basic services to the students and the development of the collection.

Besides that, most schools do not have adequate space to house the collections, equipment or the readers.

Budgets are very low, and usually not enough to cover basic acquisitions; certainly not enough to build a collection to replace the worn out materials.

On the other hand, having trained people working in the school library can be an asset. At this time there is no institution in Maldives that can provide the kind of training necessary for teacher-librarians. There has been some initial training done by the Sri Lanka Library Association, but it has not focused on the specialized needs of school personnel.

These are the basic problems and issues which have to be regarded as most obstacles that disable our libraries to be developed and to play effective roles in providing quality services to students and staff. 


\section{Special Projects}

For the time being, most remarkable on-going project or activity in the school library development area is the World Bank Aid Project. This project is providing furniture, books and other library equipment. This project is basically focused to develop libraries where the schools have more than 500 students. That is the current priority.

Future plans from the Ministry of Education for development is to establish a dedicated fund for that purpose. Through it they will be able to provide different types of continued support and aids to the schools.

MOE also plans to install some modern equipment like computers and audio visual aids in the schools across the country. This could lead to more effective service. 